The Philosophical Journal of Conflict and Violence

Vol. II, Issue 2/2018

(C) The Authors 2018

Available online at http://trivent-publishing.eu/

\title{
Samurai Culture and Christianity: A Girardian Interpretation of the Ethics of Martial Arts
}

\author{
Rodney Douglas Eadie \\ Sidney College of Divinity, Australia.
}

\begin{abstract}
This paper takes up the question of the place of martial arts in a Christian response to violence. In light of René Girard's mimetic theory, how can, or should a person of faith consider the practice of martial arts for the purposes of self-protection? This paper will respond to the question by showing that, Girard's theory situates humanity in the realm of an intermediary process awaiting the consummation of the kingdom of God. We shall discover that we are 'on the horn of a dilemma' in having to contend with the excesses of unremitting violence and the deficiencies of cowardice. A surprising compliment to Christian ethical behaviour can be found in the Eastern martial arts, which will be more closely observed through the traditions of Japanese samurai culture. We shall discover that virtue can be found in self-defence through a balance of Christian principle and martial art practice, which promotes peace and harmony in a sin-riddled world.
\end{abstract}

Keywords: René Girard; Brian Massumi; Bushido; Christianity; Samurai; Suffering; Violence; Virtue.

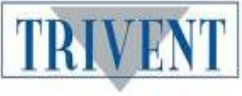

The PJCV Journal is published by Trivent Publishing.

This is an Open Access article distributed in accordance with the Creative Commons Attribution Non Commercial (CC-BY-NC-ND 4.0) license, which permits others to copy or share the article, provided original work is properly cited and that this is not done for commercial purposes. Users may not remix, transform, or build upon the material and may not distribute the modified material (http:/ / creativecommons.org/ licenses/by-nc/4.0/) 


\title{
Samurai Culture and Christianity: A Girardian Interpretation of the Ethics of Martial Arts
}

\author{
Rodney Douglas Eadie \\ Sidney College of Divinity, Australia
}

\begin{abstract}
This paper takes up the question of the place of martial arts in a Christian response to violence. In light of René Girard's mimetic theory, how can, or should a person of faith consider the practice of martial arts for the purposes of self-protection? This paper will respond to the question by showing that, Girard's theory situates humanity in the realm of an intermediary process awaiting the consummation of the kingdom of God. We shall discover that we are "on the horn of a dilemma" in having to contend with the excesses of unremitting violence and the deficiencies of cowardice. A surprising compliment to Christian ethical behaviour can be found in the Eastern martial arts, which will be more closely observed through the traditions of Japanese samurai culture. We shall discover that virtue can be found in self-defence through a balance of Christian principle and martial art practice, which promotes peace and harmony in a sin-riddled world.
\end{abstract}

Keywords: René Girard; Brian Massumi; Bushido; Christianity; Samurai; Suffering; Violence; Virtue.

\section{Introduction}

\author{
True, this! - \\ Beneath the rule of men entirely great, \\ the pen is mightier than the sword. Behold the arch- \\ enchanters wand! — itself a nothing! — But taking sorcery \\ from the master-hand to paralyse the Caesars, and to \\ strike the loud earth breathless! - Take away the sword- \\ States can be saved without it! ${ }^{1}$
}

Edward Bulwer-Lytton (1839)

Bulwer-Lytton may not have realised his master stroke of genius as pen went to paper, but his masterful poem has since caused many to contemplate its worth. It speaks of a dichotomous interplay between two powers, each a champion for their cause-one advocating communication and the other for coercion. There can be little doubt that both possess viable options to advance ideas, which has been shown throughout human history

${ }^{1}$ Edward Bulwer-Lytton, Richelieu: Or, The Conspiracy; a Play, in Five Acts. (Harvard University: Baker Publishing, 1896). Harvard University Archive, https://archive.org/details/richelieuorcons04lyttgoog (accessed May 8, 2018). 
to great effect. The problem, however, is their propensity towards power and corruption if driven by lust and desire.

With the plethora of literature, such as religious texts, historical and philosophical writings, as well as the countless cultural myths that have traversed the domain of conflict and violence, we must never forget how destructive these instruments can be when they fall into the wrong hands. If we can take any comfort at this point let it be this, there are those amongst us with noble intentions that truly seek to use complimentary aids to assist them in productive contributions towards civic virtue. Surprisingly we will discover that martial arts, even as violent and powerful as they appear to be, do just that. And even more astonishingly will be just how effective these practices can be in moderating violence and promoting peace.

\section{A Girardian Perspective on Violence and Mimesis}

One can only speculate as to how diverse the range of philosophical, religious and secular practices are when it comes to the preoccupation of peace and harmony amongst cultures and communities. It is quite reasonable to suggest that some attempts at discovering balance between the vices of unremitting violence and cowardice have come close. Even if balance is relatively achievable between these two extremes, it only ever acts in a way that meanders between conflict and conflict resolution. The prominence of René Girard's theoretical work on conflict and mimetic rivalry has heavily influenced discussions concerning violence in society. In an interview in 2009 Girard discussed the nature of mimetic rivalry from his book Battling to the End (Achever Clausewitz). ${ }^{2}$ The interview begins with Girard's interest in Clausewitz's romanticising of war. He claims that Clausewitz describes human relations in a way that refrains from suppressing the truth about human competition. Girard felt that, particularly in the West, we have an impetuous tendency to describe human relations with adjectives such as gentle and peaceful. In response to this, Girard argues the reality is that human relations were more often very competitive, which manages difference rather than doing away with it. He claims that conflict and war become more prevalent when differences between people such as social status and economics are perceived to be things hindering our happiness. Girard evidences this with an examination of archaic religions, believing they possess a structure that is foundational to the moral fabric of society. They operate in a way to control violence and distinguish between what are impure and purifying forms. When justice evolves to the point that it becomes the undergirding of indifference, Girard believes purification ceases and gives way to impure reciprocal violence. It has the inverse effect on peace. Girard writes:

Whenever the terrible equilibrium of tragedy prevails, all talk of right and wrong is futile. At that point in the conflict one can only say to the combatants: Make friends or pursue your own ruin. ${ }^{3}$

In other words, the tendency will be for society to be given either to one extreme or the other. Eventually by becoming undifferentiated, Girard believed it would result with such internal rage that society would enter into mimetic crisis. ${ }^{4}$ Girard comments:

\footnotetext{
2 René Girard, Cynthia L. Haven, "Christianity Will Be Victorious, But Only in Defeat: An Interview with René Girard," First Things (August/September 2009), https://www.firstthings.com/webexclusives/2009/07/christianity-will-be-victorious-but-only-in-defeat (accessed 07/06/18).

${ }^{3}$ René Girard, Violence and the Sacred (Baltimore, Maryland: Johns Hopkins University Press, 1979), 51.

${ }^{4}$ See René Girard, Cynthia L. Haven, "Christianity Will Be Victorious, But Only in Defeat."
} 
What I call a mimetic crisis is a situation of conflict so intense that on both sides people act the same way and talk the same way even though, or because, they are more and more hostile to each other. ${ }^{5}$

\section{A. Violence as a Constructive Tool}

Given that hostility has a propensity towards violence, Girard claims it serves at times to be a great catharsis for the release of anger and suffering. Although if violence is to be beneficial it must be controlled lest it become impure and harmful. Thus the ritual exercise of violence for community reconciliation is, "nothing more than the regular exercise of 'good' violence." ${ }^{\prime}$ Perhaps discerning between beneficial and harmful violence makes it possible that martial art traditions can be a means to control violence and quell conflict. Given that they are strict moral disciplines, makes it more likely that the arts will correspond with notions of virtue, beneficence and positive mimesis.

In light of the suggestion of martial arts, let us consider the ritualistic attachment to moral behaviours within the samurai culture. The acquisition of virtues between the vices of cowardice and unremitting violence were paramount in the execution of their martial duties. Samurai culture in this sense associates with violence bearing similarity to the religious structure identified in Girard's work. If we take into account the characteristics of purifying violence from religious archaic communities, the samurai were also creedal and communal in all dimensions, often guided by the edicts of Shintoism and Confucianism. This gave practitioners a sense of belonging and purpose, so that in context to the realities of life, violence was controlled in order to resolve conflict and guide moral behaviour.

Albeit violence may be controlled and pursued in a purifying form, by examining communities in antiquity, Girard discovered that the usual applications of violence for the resolution of conflict became prone to a cyclic pattern. This is how we come to understand the conceptual applications of the Scapegoat. In its usual form, it is the process by which a collective group's mentality perceives the victim as the unique cause of the social disorder. Interestingly, the victim is seen to be both responsible for the crisis and its resolution. As Girard puts it, the scapegoat "unites the people and saves the community." $\mathrm{He}$ also maintained the same process occurs when societies become undifferentiated. Essentially conflicts may become almost impossible to solve. Girard says, "If and when they are solved, they are solved by something that has nothing to do with rational argument." 8 This would infer a justification for the actions taken, which is the process of scapegoating, but not necessarily identifiable by those in the process. The belief here is that only via a third party may people become aware of their actions. How then do we rationalise violence to be beneficial for the resolution of conflict, and at the same time break the cycle of violence to sustain peace and longevity? The problem Girard identified with the process is that it only temporarily relieves suffering and conditions of moral impurity. Girard proposes that relief from mimetic circularity can be revealed in the innocence and divinity of Christ who "[t]riumph's over all manifestations of violence and the sacred by revealing their nothingness." This then undermines the efficiency of scapegoating.

The passion of Christ, offered through Girard's argument, may be eschatologically accepted as resolving the issue of violence; however, the intermediary process prior to the consummation of the kingdom of God is somewhat unclear. What this means is, violence

\footnotetext{
5 Ibid.

${ }^{6}$ René Girard, Violence and the Sacred, 37.

7 René Girard, Cynthia L. Haven, "Christianity Will Be Victorious, But Only in Defeat".

8 Ibid.

${ }^{9}$ René Girard, Cynthia L. Haven, "Christianity Will Be Victorious, But Only in Defeat".
} 
must be something that we contend with and we will still need to resolve conflict-even though the knowledge of Christianity will be victorious over every manifestation of violence. ${ }^{10}$ The question is, how do we achieve acknowledging Christ as the way to peace without defaulting into the process of continuing violence? In order to answer this question, we shall examine in greater detail Girard's text interpretation on the subjects of ancient myths and practices, and correlate this to Christian links in samurai culture. This will engage violence in a way that departs from suppressing differences-scapegoating and harm. It will offer a way forward in rationally resolving conflict during the intermediary process awaiting the consummate glory and show that violence can be controlled and implemented with virtue and right reason. Martial arts not only moderates violence, but it works through positive mimesis - through role play and re-enactment-acquainting us with conflict so that violence can be controlled without being violent.

\section{B. The Problem With violence}

Each community sees itself as a lonely vessel adrift in a fast ocean whose seas are sometimes calm and friendly, requirement sometimes rough and menacing. The first for staying afloat is to obey the rules of navigation dictated by the ocean itself. But the most diligent attention to these rules is no guarantee of permanent safety. The ship is far from watertight; ceaselessly, insidiously, it takes in water. Only a constant repetition of rites seems to keep it from sinking. ${ }^{11}$

\section{René Girard}

In his critique of the famous Greek tragedy Phoenician Women written by Euripides, Girard examines the use of stichomythia as two protagonists, Eteocles and Polyneices, verbally set against each other only to further champion their cause by entering into a combative challenge to rule Thebes. ${ }^{12}$ In tragedian fashion the play results in both brothers inflicting brutal and fatal blows that see them side by side on the battle field each drawing their last breath. Girard illuminates one of the first critical issues which is a notion of symmetry between combatants, as both Eteocles and Polyneices struggle to resolve their differences, and in thus failing to do so, the second critical element appears as their grievances are mimetically reflected within their respective armies. ${ }^{13}$ Girard's recognition of such establishes his argument for mimetic rivalry as violence upholds the transference of desire from its host to its sympathisers.

Girard routinely reverts to Greek tragedy because the playwrights masterfully engaged violence in a way that struck a chord deep at the core of human emotion. As Girard claims, "It has often been observed that the tragic poets cast a glimmering veil of rhetoric over the sordid realities of life." 14 In terms of violence this means that, the reality of maleficent violence is a phenomenon that is by nature a tragedy, and by fault of a common thread, a thing weaved through the fabric of humanity via the mode of desire. Girard also identifies that Greek tragedy represents the pain of human suffering that we find to be systemic in modern culture. Violent tendencies appear to be innately imbedded in human nature which surface through the fault of difference. This forms the basis for conflict and dispute. What is truly the tragedy is the resurgence of violence as mimesis takes hold within the

\footnotetext{
${ }^{10}$ René Girard, I See Satan Fall Like Ligbtning, (New York: Orbis Books, 2001),190.

${ }^{11}$ René Girard, Violence and the Sacred, 266.

12 Ibid., 44-45.

${ }^{13}$ Ibid., 45.

${ }^{14}$ Ibid., 1 .
} 
community and gathers sympathises. Girard uses Eteocles and Polyneices, as well as the manifestation of anger which can be located in The Bacchae, as an effectual and powerful way to arouse the imagination to the effects of symmetry. What is most impressive about the distinctions Girard makes is his ability to define symmetry as a common occurrence in conflict and war. The effects of desire are yet again mirrored through conflict, and if that is not enough, each combatant entices others to align in a common cause which often results in maiming or killing.

Without question Greek tragedy reeks of desire-the desire for power and the need to efface the antagonist of that desire. This endemic spreading of desire corporately precipitates into social crisis. As it takes form and manifests into a projection of ridicule, it causes the community to engage in victimisation, usually upon someone held to be the cause of the social disorder. The victim is then sacrificed bearing the shame of the community but simultaneously acting as a conduit to the sacred and divine. This revealed to Girard a crucial discovery in mythological and religious texts, showing that communities throughout history have often associated the pestilence of immorality or rebellion to be the provocation which angers the gods. As in The Bacchae, Dionysus has no other cause for rivalry with Pentheus other than to punish Pentheus for not believing that he was a god. This arrogation of divinity is nothing other than extreme (pseudo-)narcissism, and it causes Dionysus to defend his ego by inflicting an unnecessarily extreme punishment-subjecting Pentheus to bodily dismemberment. The message of such a tragedy does two things; first, it suggests that getting close to the gods can be dangerous, and secondly, if mortals anger the gods, they will be either driven to madness or to destruction.

Discovering the meaning and metaphor in Greek tragedy provokes the imagination and exposes our mortality. It elicits a hopelessness and anxiety that transcends human control. Therefore, by petitioning the gods for relief of suffering exhibits an inescapable divine dependency, and at the same time any hint of man's free-will sets out to appease the gods via ritual and sacrifice. Girard describes this scapegoating process as a metonymic relationship between members of community and ritual victims as they find it necessary to appease the gods. The immediate calm which follows is where Girard begins to deepen the understanding of "sacredness" in a way-that implies the sacred as something transcendent. The ritual process appears to be the only way to appease the gods and ensure salvation and end human suffering.

Girard concludes that the resolution to violence depends upon variables; firstly, that the manifestation of violence is mimetically reciprocated throughout communities. Secondly, aside from the forces of nature, the surrogate victim is often arbitrarily chosen. Finally, the wrath of the group is bestowed upon the surrogate victim, and in their ritual sacrifice, reconciliation is granted between the sacred and the community. ${ }^{15}$ If we consider this in light of Girard's theology, it is not hard to see that human attempts to expunge the impurities of desire and suffering through violence enter a cyclic pattern of scapegoating. A Girardian eschatology clearly identifies the fallacious attempts of human purgation and expulsion. Girard shows that maleficent violence can never be satisfied when it is shown to be a phenomenon beyond our control. If it is not a thing that can be brought under control by mortal man then Girard's argument would also suggest, that the oblation and purgation of suffering, which violence seeks to resolve, cannot be transferred to another suffering the same mortality. Girard argues, "To view violence as an impurity or blemish that is located in

${ }^{15} \mathrm{Ibid}$., 287. In addition to this, Girard denies a voluntary attribution of impurity upon the person (as in shamanism). It must also be noted this would apply to the Buddhist philosophy which suggests relief from suffering and impurity comes by virtue of seeking a life free of desire. The false dilemma in this thinking is that "seeking" is a form of desire. You cannot desire not to desire! 
a physical substance is to materialize violence once again." 16 This substantiates the redundancy of such measures and elucidates the absurdity of this mechanism, which he has evidently shown to be a repetitive condition that can never be satisfied.

The point is that by suggesting it is possible to eradicate violence through human accomplishment we only end up with violence reappearing, possibly transmuted in some way, but nevertheless failing to satisfy any lasting association with reconciliation between the subject and the sacred. Without a final resolution to this dilemma, it gives the impression that if the practice remains intact, we are on the horn of a dilemma!

\section{Violence Is of this World}

Before Girard offers a solution, he breaks down the overall problematic issues with political and social structures enmeshed in the cyclic patterns of violence and conflict. Girard discovers that a recurring pattern of behaviour using violence to quell violence is nothing but counterintuitive and divisive. His exegesis of the gospels draws an interesting distinction between the use of violence in the world and the wrath of God's judgment. Girard first demonstrates through Jesus' healing of the Gerasene demoniac (Mark 5:1-20 NASB) who, whilst possessed by the powers of Satan, submitted to the authority of Jesus. Girard argues this is paramount in understanding power structures and authority of earthly kingdoms. He correlates the principles of evil within earthly socio-political constructs being subject to the authority of the kingdom of God. ${ }^{17}$ The second crucial element to this authority is discovered after Jesus leaves a synagogue and heals a demon-possessed man. Jesus preempts the scepticism and criticisms of the Pharisees and their accusations that he is casting out demons by the power of Beelzebub and says, "Any kingdom divided against itself will not stand." (Matthew. 12:25 NASB). Girard argues this is critical in understanding any society based on the mimetic operation of expulsion, he says, "The force of expulsion always originates in Satan, and God has nothing to do with it." 18 In other words, because the force of expulsion originates in satanic powers and mimetic ritual, their modus operandi is habitually patterned through the principles and kingdoms of this world. The cultural order of the mechanism is presented as the bane of our existence. Girard offers one solution:

Once the basic mechanism is revealed, the scapegoat mechanism, that expulsion of violence by violence, is rendered useless by the revelation. It is no longer of interest. The interest of the Gospels lies in the future offered mankind by this revelation, the end of Satan's mechanism. The good news is that scapegoats can no longer save men, truth shines into dark places. God is not violent, the true God has nothing to do with violence, and he speaks to us not through distant intermediaries but directly. The Son he sends us is one with him. The kingdom of God is at hand. ${ }^{19}$

Girard's work builds with intensity as it points to Christ as the perfect sacrifice. He has masterfully captivated the reader by implicating them into the plot of biblical narrative. Nevertheless, the reader will now find themselves at cross-roads having been presented with a dilemma. Girard implores the reader to embrace a revelation of Christ, and to consider the offer to escape the cyclic pattern of violence through Jesus the first Paraclete. Christ who

\footnotetext{
16 Ibid., 287.

17 René Girard, The Scapegoat, trans. Yvonne Freccero (Baltimore, Maryland: The Johns Hopkins University Press, 1989), 187.

${ }^{18}$ Ibid., 189.

${ }^{19}$ Ibid., 189.
} 
took on human form stands in substitution of the imperfect sacrifice. By having this revelation of the work of Christ is a courageous step toward overcoming violence. If we have faith in Christ, even though his presence resides in a divine kingdom, we are assured comfort from the Holy Spirit-the second Paraclete. ${ }^{20}$ By faith we find security and comfort believing He will provide us our strength and instruction (John 14:25-26 NASB), and to hold fast to the truth in times of persecution (John 16:1-4 NASB). In conclusion to his theoretical account of violence, Girard leaves us with this notion regarding all things violent and sacred:

In future, all violence will reveal what Christ's Passion revealed, the foolish genesis of bloodstained idols and the false gods of religion, politics, and ideologies. The murderers remain convinced of the worthiness of their sacrifices. They too, know not what they do, and we must forgive them. The time has come for us to forgive one another. If we wait longer there will not be time enough. ${ }^{21}$

This of course presents the solution in its entirety, but it also calls our minds to this dilemma of having to cope with violence and the use of force here and now. Girard has thus far preoccupied our minds with an eschatology of violence, but really offers nothing in the way of strategically managing violence and force in practical matters until the consummation of God's kingdom. Even if martyrdom is the call to which one may answer against the injustices and demonic powers, we are also called to fight against the principalities of this world - if they stand contrary in nature to the laws of God (Ephesians 6:12 NASB). As we shall see in the next part of this work, martial arts can be viewed with a means of instilling efficacy, whereby-at least from a Christian perspective-one can support and retain an ability to confidently pursue what is right and what is virtuous during periods of conflict.

\section{The Path of the Warrior Is Laden with Humility}

\section{A. There Is More to Fighting than Meets the Eye}

Samurai traditions can be traced back as far as $794 \mathrm{CE}^{22}$, but the codified practice of such arts is not distinctly Japanese either. Philosopher and martial artist Damon Young draws our attention to the likes of Socrates who was a respected soldier and to Plato who earned his nickname due to his broad shoulders and wrestling prowess. ${ }^{23}$ Young describes a cohesion of Western philosophy to martial arts and believes they existed in ancient Greece as "happy bedfellows". ${ }^{24}$ From Young's interpretation, it appears the historical roots of Western philosophy teach us to analyse our relationship to the world, and that the martial arts help to provide us with a practical means to engage it. ${ }^{25}$ Young identifies an important correlation that exists between Eastern and Western traditions in the focus of what the Greeks called $\tau \dot{\varepsilon} \chi \vee \eta$ (techne meaning art or skill) and $\tilde{\eta} \theta 0 \varsigma$ (ethos meaning ones character and

\footnotetext{
${ }^{20}$ Ibid., 208.

${ }^{21}$ Ibid., 212. See also René Girard, Things Hidden Since the Foundation of the World (Stanford, California: Stanford University Press, 1987), book II, chapter 3 for a complete reading of the sacrificial historicity of Christianity.

22 Tadao Otaki and Donn F. Draeger, Judo Formal Tecbniques: A Complete Guide to Kodokan Randori no Kata (Vermont, USA: Tuttle Publishing, 2001), 19.

${ }^{23}$ Damon Young, Martial Arts and Philosophy: Beating and Notbingness. (Chicago, Illinois: Open Court Publishing, 2010), $\mathrm{x}$.

${ }^{24}$ Ibid., x.

25 Ibid., 6.
} 
way of doing). ${ }^{26} \tau \dot{\varepsilon} \chi \nu \eta$ and $\tilde{\eta} \theta 0 \varsigma$ resemble in nature similar characteristics to the Japanese terms bu (martial) and do (the way) which form budo or the way of martial arts, of which were generally practiced by chivalric warriors of feudal Japan. Both traditions heavily concrete this aspect of performance to ethics as critical in the formation of being. Young believes they are happy bedfellows but considering the gravity to which they contribute to what is just and right, they are not simply conjoined terms, in fact many scholars have argued they act in accord necessitating one another's existence. ${ }^{27}$

Indeed, this highlights a very simple notion that martial arts/self-_defence practice should be governed by principle, and that when $\tau \dot{\varepsilon} \chi \vee \eta ~ a n d \_\tilde{\eta} \theta 0 \varsigma$ come into harmony, there is often more clarity between what the mind thinks and what the body can do. Although, if all that we gain from these terms is a modulating effect to behaviour then we have not engaged the topic through the mind of one practicing budo.

A student of budo is committed to Bushido (way of the warrior) and volunteers themselves to a lifelong journey of chivalry. They apprentice under a master, discipular by means of replicating the traditions of the samurai-given to the study of combatives and virtue ethics. These could be defined as; righteousness, courage, respect, loyalty, benevolence, honesty and honour. ${ }^{28}$ This would have the samurai perform every task with mindfulness and gratitude, including care taken to discuss philosophical advancement of battle tactics and combative skills. Outwardly, it would appear that samurai were conscious of publicly demonstrating their piety and wisdom in order to protect their name-which was perceived to be the bearer of their soul. Great works were not only honourable, but they would ensure immortalising the soul of samurai.

Moral behaviour was vital to samurai training but then again so was the mind. Having a presence of mind in harmony with the body and the external world relied upon the notion of non-resistance. For example, if it were cold one would resist the urge to fight against it, instead opting to embrace it and learn how to cope with the cold. Everything that is subjective, consciousness and corporeity, disciplines itself in the mastery of restraining oneself between vices offered by the external world.

To imagine samurai practice, one must conceive a life devoted to this notion of restraint. Violence, in the world of Bushido, is just another phenomenon that must be understood. Therefore, rather than resisting it, the samurai learned to embrace its value. In fact, history reveals martial arts is the mastery of violence, but strangely enough it is mastered and subdued by the mind and reconditioned as a beneficial aid to protect and serve others. A force to empower!

In order to empower the self and others, one must be diligent in the applications of restraint, thus avoiding a use of force that would otherwise indulge in revenge and resentment. This begs the question though, how is it that it is possible to attribute virtue to the concept of violence? The key to such thinking is contained in the logic of nonresistance. As has been revealed, samurai instead of resisting the effects of violence, rather embraced methods of combat as countermeasures to the excesses of rashness, revenge and

\footnotetext{
26 Ibid., 6.

27 Nitobe wrote extensively on the Chivalric traditions of samurai culture. He specifically defines the character role of samurai as martial artists, that they are burdened by the precepts of knighthood, noblesse oblige within the warrior class. The codified characteristics of Bushido differentiates the arts from other sports. Martial arts, in practice, are often relegated to the sporting arena for observation and athleticism, however, they remain distinctly and uniquely ethical systems of military combat, designed for the purposes of justice and the wellbeing of others in daily life See Inazo Nitobe, The Way of the Samurai (London: Arcturus Publishing, 2016), 20.

28 History.com editors, "Samurai and Bushido" (October 28, 2009), https://www.history.com/topics/samurai-and-bushido (accessed May 10, 2018).
} 
resentment—characteristics that are usually attributed to mimetic rivalry. Equally this would serve to guard against cowardice and self-loathing, as it was purifying in its own right. Given time and understanding, the path of bushido discovered within the practice of combatives, under a framework of restraint, there existed certain characteristics that enhanced the quality of life. This process of refinement has led to what may now be understood as fashioning violence into virtue.

For the modern martial art enthusiast, in order to begin understanding how this is possible will require a little unpacking. One of the foremost leading scholars on the power of violence, Brian Massumi, puts it like this, "Physical violence, in its superempirical dimension, saturates the space between bodies." ${ }^{29}$ Massumi's description of violence suggests that its effect as a force in the dynamics of relationships is by nature a source of power. Power is something used effectively (purifying) or degradingly (impure), that is, we can be empowered, or we can use power to overcome. According to Massumi, when society is operating on a dynamic equilibrium people are empowered, but when violence awakens it generally operates from one source of power attempting to overpower another. The most effective application of force extracted from violence is what Massumi calls force-to-owntime. ${ }^{30}$ In saying this, Massumi does not necessarily mean that force be excessive. For example, Newton's third law suggests that the magnitude between forces may be equal but opposite in direction. Massumi is stating that action-reaction can be quite effective. If a figure skater flings his female partner in front of him to land in a forward force of action, the force of the man is equal in magnitude yet opposite in direction to the force of the woman. Yet, the acceleration of the woman is greater than the acceleration of the man.

In this analogy we gain a better sense of what Massumi is suggesting when it comes to extracting or moderating violence. The force applied can be necessary but never operating in a way that is excessive or beyond its measure. In a similar sense, samurai were premised by a code of ethics that determined their behaviour in the face of the enemy that was equal in magnitude yet opposite in force. This is what is meant by the essence of budo being malleable and yielding. The efficiency of budo operates to be free from the urge or impulse to anger and to control desire rather than desire having controlled the individual. Violence on the other hand is often thought to be organised dissent, or the expression of disagreement, or the reactive state of

lust and desire. ${ }^{31}$ Massumi claims, "In its immaterial dimension of threat, violence propagates nonsensuously from body to body." 32 It spreads like a contagion feeding from the mood of its hosts. Massumi's identification of threat reflects in much the same fashion Girard's symmetry and mimesis. This correlation can be drawn as Girard and Massumi pay recognition to the septicity of violence as a societal weakness. On the other hand, the path of bushido mechanised a utility of force from violence, not merely as a means to stabilise peace, but as a way to live peaceably amidst conflict. It meant respecting its essence which

\footnotetext{
${ }_{29}$ Brian Massumi, Ontopower: War, Powers, and the State of Perception (Durham, London: Duke University Press, 2015), 87.

30 Massumi's use of the term "dynamic equilibrium" expresses the use of force in society that is beneficial to conflict resolution. The equilibrium in this sense is closer to a celebration of difference rather than a passive acceptance of social indifference described by Girard. Massumi's definition of force-to-own-time correlates to the ethical systems of Bushido and non-resistance. Being non-resistant and non-violent is predicated by a mindset that applies force for the sake of peace. Absorbing the hostility of an aggressor does not instinctively require a violent response. The return of an application of force may be non-violent and yielding, set in stark contrast to the belligerent attitude of the attacker. See also Nitobe's comments regarding benevolence in samurai culture and the term "Bushi no nasake" which defines the tenderness of a warrior (The Way of the Samurai, 48).

31 Brian Massumi, Ontopower: War, Powers, and the State of Perception, 72-73.

32 Ibid., 87.
} 
was possessive of kami (spirits, god or deity), believing kami to be incarnated into all things. ${ }^{33}$ That would entail all things animate and inanimate being respected, especially when human effort was applied for the sake of another. This is why the performance of combative arts, a thing possessing human effort, was to be respected as well.

Enshrined in the combative forms of martial arts is this deep sense of moral behaviour and social etiquette. It has become the Japanese way of doing things, to master technique and skill-attributing honour to the effort behind the object. A Westerner merely observes a cup as an object to serve them, whereas, the Japanese observe the effort going into the production of the cup as a most honourable task. ${ }^{34}$ The way of the warrior encompasses all of these qualities by embracing this spiritual connection in the effort given to every technique. Every movement requires diligence with a mind to master it. The mindfulness steering the technique is neither given too deep to it, nor is it distracted from it. Not a single technique or move of the body should be wasted. The body then, in unison, becomes the expression of a malleable and yielding force, never excited beyond its purpose and always honoured as an effort that serves. When the mind and body perform in such a manner, they act honourably and seek virtue between vices in psychosomatic union.

It is possible to conceive that a mechanism, so concentrated as the martial arts, can possess the ability to serve humanity in a way that reorders acts of violence into acts of virtue. For example; beyond the arguments for just war, which this work cannot grant such latitude, the samurai would practice jujutsu—which can be described in colloquial terms as "the gentle art". If one is to practice the gentle art as such, it is premised on the concept of a weaker person overcoming a much stronger adversary through the effective use of leverage and technique. The basis for this idea is always self-defence and never given to the maxims of vice either side of the equation. Therefore, an act of righteous anger is not an act of revenge and it certainly will not give in to cowardice. Anger must always bear in mind forgiveness and understanding, which means the principle governing the practice is directed towards peace. If a violent adversary strikes a blow, jujutsu is employable as a means of averting danger and simultaneously restraining and nullifying further aggression. The mechanistic value of martial arts uses force through absorption, extracting from an illintended act and redirecting and reordering force so that it is no longer capable of threatening and harming.

This rather well-thought-out application of Zen in budo has greatly influenced martial practice since its inception in Japan during the twelfth century CE. It also calls to mind a reimaging of mimesis in a positive light. In contrast to its counterpart "rivalry," a student of budo may desire to emulate the prowess and morality of his master. The absorbing of violent content is subjectified and reconstituted to serve with honour and respect. It is diffused of its violent energy and projection.

Religious practice often accompanied martial skill with a concept of mindfulness and diligence that could be applied to every aspect of life in general. There was such an emphasis on being presently aware that practitioners became neither fixed nor focussed on extremes of emotions. The hope of such a devout life of course was to eventually reach a state of nirvana, which was viewed as an achievable goal so long as the practitioner adheres to four noble truths - those being; the truth of suffering, the truth of the origin of suffering, the truth of the cessation of suffering and the truth of the path. ${ }^{35}$

Eastern religion has long taught that suffering originates from human desire which is attributed to an ignorance and misconception about the nature of self and its relationship to

\footnotetext{
${ }^{33}$ Michael D. Coogan, World Religions. (London: Duncan Baird Publishers, 2003), 171.

${ }^{34}$ Ibid., $72-73$.

35 Ibid., 171.
} 
things around it. ${ }^{36}$ Practitioners of budo who subscribe to Zen teaching believe that suffering will cease when the process of suffering is reversed. Therefore, a great deal of emphasis is placed on the individual to undergo a constant cathartic process of ritual expulsion, similar in a sense to a self-expungement of impurity. At this point we have some contradictions with the spiritual teaching that is so often associated with martial arts, and Girard's scapegoat theory assists in recognising these inconsistencies.

The principles associated with ritual expulsion of suffering require a deep symbiotic union of mind and body. In Buddhist and Confucian thought, the chief responsibilities for perception and human sensorium are required to cohabit which is why ritual practice is necessary in reaching harmony. Unrestrained desire would be considered the chieftain of suffering which unsettles the body's equilibrium. In Confucian literature it is argued that a ritual process of goodness is the restraint of desire. ${ }^{37}$ Once that is understood, then a training of the mind and body becomes a ritual of goodness which deprives desire of its stronghold. When this is achieved, then suffering is thought to cease. In response, the practitioner considers it their duty to assist others in cultivating such virtues by "lifting the veil" of illusion that has shrouded them in their ordinary experience. ${ }^{38}$

Prima facie it appears this ritual process of goodness avoids a third-party concept of scapegoating to expunge suffering. The problem of course was identified earlier in Girard's argument. He suggested that desire is the cause of both violence and suffering, to which it cannot be bifurcated from the communal to the individual. Even through a concerted individual effort to expunge desire and violence, it cannot be thought of in terms of "it" having substance or as an object. If desire results from a misconception of self to its environment, then desire has been objectified as a thing. If Girard's theory holds true, then the need for a perfect solution to suffering and violence means that, desire is an innate characteristic of imperfect human beings. This cannot be rectified through ritual goodness, because no amount of goodness is good enough. Ritual goodness is a torturous selfdeprecating act attempting to locate desire as an impurity within the self. The result of such ritualism leads only to materialising the impurity as substance-as something that must be expunged.

If the misconception of self is shrouded in ordinary experience, then the duty owed to others is to reveal the state of ignorance and desire. This act of generosity requires no tradeoff per se, although what is reciprocated is usually an extended courtesy and appreciation which carries on from person to person. This is somewhat of an active ingredient in the life of a martial arts practitioner, and there are few exceptions when it comes to its performance and applications.

In book I of the classic texts of bushido, Yamaga Soko summarises one's obligation to morality owing it to the integrity of humanity and justness. Soko shows that treading the path of budo calls for a life dedicated to this highest quality of human character. He demands the outwardness of one's life be the expression of a just heart and further adds that this will steer the process of intelligence. ${ }^{39}$ Soko insists that it is only possible to exhume such characteristics if the warrior first submits his mind to making peace with destiny, requiring from him a synchronicity of mind, body and spirit that is unconcerned

\footnotetext{
36 Ibid., 175.

37 Wan Yang, "Conception of Moderate Desire in Confucian Thought on Goodness and its Realistic Significance," The Eternal Way 2 (2003), http://www.confuchina.com/03\%20lunlizhengzhi/Conception $\% 20$ of $\% 20$ Moderate $\% 20$ Desire.htm (accessed June 13, 2018).

38 Michael D. Coogan, World Religions, 176.

39 Thomas Cleary, Samurai Wisdom: Lessons from Japan's Warrior Culture. Vermont (North Clarendon, Vermont: Tuttle Publishing, 2009), 59.
} 
with riches and rank. ${ }^{40}$ This act of submission resembles aspects of the Christian life, which according to Matthew (16:24 NASB), suggests an element of denial of self over and against the impulses and urges of the esteemed life. It would appear that self-veneration is the antagonist in Buddhist, Shinto and Christian teaching, and that the lowly pursuit of humility is the protagonist of good living.

\section{Complimenting Christianity with Budo}

\section{A. Bridging the Great Divide!}

The present discussion has thus far excluded two key elements: the explicit link between Christianity and budo and the ability for such cohesion to dissolve violence and act with virtuous intent. The model from which to base such a mechanism builds upon the foundations of samurai converts during the Tokugawa period (1603-1868), and the succession of those converts post Meiji restoration (1868-1912) ${ }^{41}$ Christian missionaries such as Alessandro Valignano and Francis Xavier SJ saw a rapid expansion of Christianity in Japan at the beginning of the Tokugawa Shogunate, however; the Tokugawa ruling class are said to have merely tolerated the presence of Christianity, so long as it did not hinder social and political mandates to bring a common people into acquiescence. ${ }^{42}$ Over time political relationships deteriorated due to tensions amounting from Christianity influencing the social fabric of Japanese culture. This caused dissention in the ranks of the samurai, as some were devout disciples of Christ whilst others remained sceptical and disapproved of the pace at which Japanese culture was moving.

The famous samurai convert Baba Bunko observed some of his colleagues corrupting the samurai position and so in an act of protest removed himself from power. Bunko's devotion to Christianity ethically challenged the elite by calling for transparency in their behaviour. The edicts of Christianity would inevitably create angst for some of the ruling class, but the most displeasing aspect of Christianity appeared not to be a progressive move of acculturation, instead it was the strangeness of worshiping a God that allowed himself to be killed by human beings — which for the ruling class resembled weakness in leadership.

In the life and theology of Bunko, a reimaging of budo affirmed such things as; commitment, loyalty, righteousness and spirituality, to be qualities of an individual who is subject to the authority of the one true God. Bunko's life was prostrate before God, devout to the discipline so that his witness would manifestly express that God is love (1 John 4:8 $\mathrm{NASB}$ ), that $\mathrm{He}$ is the creator and redeemer of humanity. ${ }^{43}$ Bunko's committed faith correlated to many Buddhist and Shinto teachings, but what Bunko presented as the most challenging for the Tokugawa bakufu (government), was that hypocrisy cannot be veiled by the outward appearance of Buddhist traditions. Bunko is an exemplar of the life of a samurai reimaged. He reaffirmed one of its most valuable assets, a code which to live by that governs ethical behaviour and shapes the course of one's life. That is an essential component to the martial artist, but as Bunko realised, the imperfections of humanity cannot be individually rectified, they must be held to account and justly dealt with beyond human measure. In an age where individuals were so used to resolving shame through ritual, the offer of grace, if not understood correctly, was too unbearable.

\footnotetext{
40 Ibid., 41.

${ }^{41}$ See History.com editors, "Samurai and Bushido".

${ }^{42}$ Costa Oliveira, Joāo Paulo, "Tokugawa Ieyasu and the Christian Daimyo during the Crisis Of 1600," Bulletin of Portuguese - Japanese Studies (2003): 48-49.

${ }^{43}$ Koichi Tohei, Aikido: The Co-ordination of Mind and Body for Self-defence (London: Souvenir Press, 2000), 34 .
} 
Samurai had typically viewed the ritual seppuku (suicide) as the only means by which one could publicly accept responsibility for their shortcomings, as well as ensuring the honour of their name (considered to be their soul) was restored to eternal glory. ${ }^{44}$ The honour of samurai was found, in rectitude and right reason, displayed through the distinction of knowing what to fear and what not to fear. Their sincerity towards honour and shame iterated the importance of national interest over personal interests. ${ }^{45}$ These admirable qualities of self-denial manifested virtues of benevolence and politeness which were of the highest characteristics of chivalry. ${ }^{46}$ As a way of life it was certainly reminiscent of European chivalric and Christian traditions who were equally given to a thoughtful life and mastery of practice. Without good practice it would simply remain nothing but thought, ${ }^{47}$ although mastery of etiquette along the path of bushido was to the foreigner rather arduously eccentric. For the samurai, such attention to detail displayed courtesy and a politeness which held the mind captive to distract it from pursuing evil. ${ }^{48}$ Again it resembles similarity to Christian thinking, especially when we reflect upon the words of St Paul who wrote, "Finally, brethren, whatever is true, whatever is honourable, whatever is right, whatever is pure, whatever is lovely, whatever is of good repute, if there is any excellence and if anything worthy of praise, dwell on these things." (Philippians 4:8 NASB).

A distinction that must be drawn at this point was that the ritualism of samurai culture was incompatible with Christianity at the intersection of immorality. Even with an overlapping vis-à-vis the virtuous life between faiths, from a Christian perspective, ritual suicide was not capable of offering relief

and restoring honour as taught in the Japanese chivalric traditions. For samurai such as Bunko the treatment of immorality and shame meant conceding to failure, a failure to right an eternal wrong of a nature imbued with an impurity that cannot be found in substance or form. The dishonour this brings creates a dilemma when viewed through samurai tradition. Unbearable shame can only be remedied by an act of ritual suicide. The problem with seppuku is that it reverts back to the ritual expulsion identified by Girard-which would relegate this form of ritualism to a form of scapegoating. It is purely subjective, but the ritual itself acts in a way that is perceived sacred. In the end, according to the Girardian perspective, it fails to overcome the manifestations of violence. It has not prevented nor conquered violence. It has merely made of use of it to forcibly put an end to a social disorder.

For the samurai mind possessive of the truth claims of Christianity, there was now an offer to restore a shameful guilt-laden soul but only if it were believed that it came via the gift of Christ. It is understandable that, existing in such an honour system, it was hard to accept that an eternal debt was remunerated by grace. Notwithstanding such hard-line doctrine, many samurai accepted this truth and reimaged their convictions and commission.

The Kirishitan "Christian life" offered a way of practice and principles bearing similarities to bushido but reimaged as a service to extol the gift of grace. It was a life equally devoted to doctrine and virtuous living which bridged communication between cultures bound by religious order. The call to servanthood as a Christian practitioner of budo was a new way of conceiving discipleship as self-sacrificial. Equally, as the Christian learned of the performance of bushido, they were in a better position to conceive samurai service as

\footnotetext{
44 Takemi Sasamori, Bushido and Christianity, trans.Mark Hague (Tokyo Japan: Reigakudo Press, 2016), 106.

45 Inazo Nitobe, The Way of the Samurai, 39.

46 Ibid., 55.

47 Takemi Sasamori, Bushido and Christianity, 62.

48 Inazo Nitobe, The Way of the Samurai, 56.
} 
something transcending fighting against the flesh. It did not diminish the honour associated with sacrifice for one's master, it only heightened the sense of worthiness to what discipleship really meant. By this new image of service, it would be possible to comprehend what Jesus meant by saying, "Greater love has no one than this: to lay down one's life for one's friends." - (John 15:13 NASB).

The concept of bushido is therefore a sensible notion, provided the performance of martial arts is done with a righteous heart defending principle of morality for the sake of another, especially when it exemplifies the love of Christ. The contrast of Christian samurai to its former self is this, that a conscious mind dedicated to the practice of budo done with a self-sacrificial devotion to Christian discipleship is a life devoted in service to the betterment of humanity. It remains consistent with the chief task of seeking to lift the veil of desire and relieve suffering, although premised by a new principle of being as a new creation in Christ. The movement of martial arts becomes an outward expression of an inward grace. It is a performance requiring dedicated effort (Ecclesiastes 9:10 NASB) which demonstrates that the mind can be given entirely to the service of God, not man (Colossians 3:23 NASB).

When it comes to the bodily performance, martial art movement is unlike other sports or crafts. They possess the ability to express human degradation beyond all other means. Violence when uncontrolled can pervert creation, it can humiliate rather than extol, and it can manipulate and corrupt what God made good. It has the power to protect life or take it. There is nothing more terrifying and unforgiving than violence unrestrained. It is not the sword of the samurai nor the gun of the soldier which is evil, they are but mere implements designed to serve. Rather it is the mind which guides the weapon that determines its use. In King Solomon's great wisdom, he wrote, "Watch over your heart with all diligence, for from it flow the springs of life" (Proverbs 4:23 NASB).

The guidelines governing the explicit use of force are hidden within the reimaging of self. By acting responsibly with the gift of martial skill allows one to extract force from violence, and to see it fashioned into a by-product of that virtuous mind. The form and content of martial arts should synthesise and manifest this new manufacturing of an identity in Christ. When it is done in such a frame of mind, replicated from the examples of Christian samurai such as Bunko, then violence can be absorbed and fashioned into virtue through positive mimesis. It becomes merely a projection of outward energy, expressing the content of the mind through form. If it is a projection of peace and love aimed at minimising harm, then it truly serves as a complimentary aid to the Christian life.

We have thus entered a new state of being that can harmonise, or in other terms, synchronise the mind/body experience by using Christian principles to guide martial arts in order to respond to our initial predicament. The dilemma presented to us in having to contend with unremitting violence and the deficiencies of cowardice is finally recognised through Christ as having sufficiently overcome the burden of desire and suffering. In Christ, if we seek a course of action that qualifies under the auspice of discipleship, then we no longer act to suppress suffering and materialise it over again. Any mechanism of actual physicality, in the form of martial arts, acts primarily in the intermediary process in anticipation of the consummation of the kingdom of God. There has to be a "middleground" in light of transitioning from one state of being to another. Martial arts is certainly a method to accommodate Christians in contending with violence and conflict. Bunko never relinquished the responsibilities of a samurai, he only protested against corruption he witnessed in the Bakufu Shogunate. His conversion to Christianity and adoption of its ethical standards for behaviour, paved the way for many daimyo and samurai to come to faith and seek honourable service as practitioners of budo. In his life and theology, we find an exemplar of Christian discipleship undergirded by principles that guide practice. This constitutes a physicality within martial arts that is congruent in mindfulness to what was 
expected of samurai, but thoughtful enough, that in response to violence and conflict acts antithetical to the bellicose attitude of a misguided violent person.

\section{B. Overcoming the Dilemma}

To ensure that one seeks virtue between the maxims of violence and cowardice, it is necessary that cognitive adaption when conceptualising the rules of force must abdicate from the cyclic processes of ritual sacrifice. If we are to think with a Girardian mindset, a theology of martial arts can undoubtedly be a contribution to civic virtue, but it must act without inversely reflecting the problems of mimetic rivalry and scapegoating. Christians who trod the path of bushido were able to achieve this synchronicity between vices. They immersed their thinking in the scriptures so that their actions imitated the life of Jesus. As they moved through the world and participated in it, martial arts through the eye of a samurai had the ability to move the practitioner from the aesthetic dimension on the fringes, to a full existential dimension of active engagement. The methods and principles that guided their practice ensured deeper understanding of love, violence, peace, grace and humility as all shared characteristics of the human experience. It was practiced in the dojo (training hall), but always extended beyond that environment to form an important social control.

This phenomenon of marital arts and self-defence models for us a way of controlling violence and is defended as appropriately mediated acts of force. In other words, it is violence that has been apprehended by the mind and fashioned into virtue. By introducing Christ as the form to imitate ensures that martial art practice draws us deeper into the human experience and recognising that He has satisfied all matters of reconciliation-not us.

\section{Martial Arts Are the Way to Practically Control Violence}

A crucial element to the success of martial arts has always been in the training. The path of bushido, as discussed, was a disciplined life harnessing skills and breaking down each movement into digestible chunks for the mind to absorb. This process is rather mechanised so that it allows necessary ethical standards to be attributed to its practice. For that to happen it must occur in the dojo so that the mind can apprehend the violence and reconstitute it under pressure. It has been a part of an age-old custom within martial practice to engage with others in the safety of this environment, breaking it down and gaining control over its power.

The samurai, in their dojo experiences, would undergo frustration, disappointment, a loss of control and learn to accept that their success is built upon their previous failures. This fails to be recognised by the untrained mind. If violence is not controlled in this fashion, then there is no way to gauge between restrained and unremitting violence. When samurai trained, they increased their knowledge in losing just as much as they did through success. A failure and loss caused deep reflection with vivid imagination, a kind of soulsearching journey as they imagine their opponent bringing them to the brink of death but withholding because of moral conviction. With a simple tap conceding defeat the loser embraces his opponent with gratitude and respect, knowing very well that their life was handed back to them. The winner learns to be gracious in victory because they too have personally experienced the pain of losing. The dojo experience has routinely become a place of continual refinement, and like scripture, it has a habit of exposing human frailty and vulnerability.

The concept of apprehending violence suggests this; that a cognitive adaptation occurs that moderates the extremes of violence and simultaneously prevents one from entering into cowardice or uncontrollable aggression. The practitioner becomes a moderator that 
possesses skills to counter harm, and by refinement has absorbed enough content to mitigate that threat. This of course begins with prudence and knowledge, which Aristotle believed led to virtue, ${ }^{49}$ and with that in mind it begins a journey capable of reaching the highest elements of human flourishing.

What has been proposed in this examination is a way to live peaceably in society, whereby conflict can be resolved through the apprehension and control of violence. The manner by which this can occur is offered through the practice of martial arts guided by Christian principle. Not only is it beneficial in resolving conflict, but it also links us to the forefathers of the Christian samurai. For the modern disciple of Christ, particularly for those convinced that martial arts are a complimentary aid, the life of the Christian samurai is an exemplar model of principle and practice that guides our morality and behaviour. The historical correlation enables us, in a post-modern culture, to

conceive living between the extremes of unremitting violence and the deficiencies of cowardice. And in light of this, just as the Christian samurai once walked this path of synchronicity in great harmony, we too can responsibly manage the ongoing saga of violence in anticipation of the kingdom of God.

It is possible within our minds to apprehend violence as a phenomenon that becomes a source of power beneficial to peaceable living. If we view others in the image of God, that is, seeing within them the innocence of Christ-a person redeemed, sanctified and reconciled; our applications of force may express the inward grace bestowed upon us. Through the malleable and yielding characteristics of a theologically defined martial art, one may act without advantage or prejudice towards others. It provides for us a confidence to pursue peace amidst conflict, because we possess a method for taking violence and stripping it of its impurity. With such foresight, it is possible to rationally dissolve conflict and avoid forcibly appropriating its use to power-over.

Martial arts is defended here as a non-violent complimentary aid to discipleship. It can quell violence and must act out of peace to diffuse violent acts. As an outward expression of an inward grace it must seek to divorce violence of its capacity to own time. In its performance, it must refrain from mirroring its adversary.

\section{References}

Aristotle. Nicomachean Ethics. Translated by Terence Irwin. Indianapolis, Cambridge: Hackett Publishing, 1999.

Bulwer-Lytton, Edward. Richelieu: Or, the Conspiracy; a Play, in Five Acts. Harvard University: Baker Publishing, 1896.

Cleary, Thomas. Samurai Wisdom: Lessons From Japan's Warrior Culture. Vermont, USA: Tuttle Publishing, 2009.

Cartwright, Mark. "Samurai". Ancient History Encyclopedia (2017). https://www.ancient.eu/Samurai/ (accessed May 4, 2018).

Coldren, David A. "Literature of Bushidō: Loyalty, Honorable Death, and the Evolution of the Samurai Ideal," International Research Scape

Journal 1 (2014), http://scholarworks.bgsu.edu/irj/vol1/iss1/2 (accessed May 5, 2018). Coogan, Michael D. World Religions. London: Duncan Baird Publishers, 2003.

Girard, René. I See Satan Fall Like Lightning. New York: Orbis Books, 2001.

49 Aristotle, Nicomachean Ethics, trans. Terence Irwin. (Indianapolis, Cambridge: Hackett Publishing, 1999), 98 . 
Things Hidden Since the Foundation of the World. Stanford, California: Stanford

University Press, 1987.

The Scapegoat. Translated by Yvonne Freccero. Baltimore, Maryland: The Johns

Hopkins University Press, 1989.

.Violence and the Sacred. Baltimore, Maryland: The Johns Hopkins University Press, 1979 .

History.com editors. "Samurai and Bushido" (October 28, 2009).

https://www.history.com/topics/samurai-and-bushido (Accessed May 10, 2018).

Massumi, Brian. Ontopower: War, Powers, and the State of Perception. Durham, London: Duke University Press, 2015.

Nitobe, Inazo. The Way of the Samurai. London: Arcturus Publishing, 2016)

Oliveira, Costa \& Joāo Paulo. "Tokugawa Ieyasu and the Christian Daimyo during the Crisis Of 1600.” Bulletin of Portuguese — Japanese Studies (2003): 48-49.

Otaki, Tadao and Donn F. Draeger. Judo Formal Techniques: A Complete Guide to Kodokan Randori no Kata. Vermont, USA: Tuttle Publishing, 2001.

Ritch, Charlie. "The Possibility of a Christian Appropriation of Aristotle's Ethical Philosophy." Aporia 14/1 (2004). http:/ /aporia.byu.edu/site.php?id=spring2004 (accessed May 25, 2018).

Tohei, Koichi. Aikido: The Co-ordination of Mind and Body for Self-defence. London: Souvenir Press, 2000.

Yang Wan. "Conception of Moderate Desire in Confucian Thought on Goodness and its Realistic Significance." The Eternal Way 2 (2003).

http://www.confuchina.com/03\%20lunlizhengzhi/Conception $\% 20$ of $\% 20$ Moderate $\% 2$ ODesire.htm (accessed June 13, 2018).

Young, Damon. Martial Arts and Philosophy: Beating and Nothingness. Chicago, Illinois: Open Court Publishing, 2010. 